\title{
Application of microorganisms, alone or in combination, to control postbloom fruit drop in citrus
}

\author{
Mariana N. Klein ${ }^{1}$, Aline C. Silva ${ }^{1}$, Marcos R. Lopes ${ }^{1} \&$ Katia C. Kupper $^{2}$ \\ ${ }^{1}$ Universidade Federal de São Carlos, 13600-970, Araras, SP, Brazil; ${ }^{2}$ Centro de Citricultura Sylvio Moreira, Instituto \\ Agronômico de Campinas, 13490-970, Cordeirópolis, SP, Brazil
}

Author for correspondence: Katia Cristina Kupper, e-mail: katia@centrodecitricultura.br

\begin{abstract}
Isolates of Trichoderma spp. (ACB-14, ACB-33, ACB-37, and ACB-40) and Bacillus subtilis (ACB-66, ACB-69, ACB-77, and ACB-83) were tested separately or in mixtures for suppression of postbloom fruit drop in citrus, caused by Colletotrichum acutatum. This work aimed at: (i) determining the incubation time and temperature for production of cells of biocontrol agents; (ii) determining the effect of the isolates, separately or in mixture on the germination conidia of C. acutatum; (iii) evaluating the efficiency of antagonistic isolates on detached citrus flowers and under field conditions. The results of the interactions in vitro showed that there was little differentiation in cell production among the species, and the optimum temperature was $27^{\circ} \mathrm{C}$. The best time for multiplication of bacterial cells was 36 hours, whereas for Trichoderma, the production of conidia continued to increase up to 120 hours of incubation. The mixtures of the ACB-77 plus ACB-66, ACB-33, or ACB-37 inhibited pathogen germination from 84\% to 89\%. Studies with detached citrus flowers showed that ACB69 alone gave $99 \%$ control. The use of mixture ACB- 69 plus ACB-37 proved to be viable in the control of disease under field conditions, but the efficiency of the control was lowest than the obtained by applications of ACB-69 alone.
\end{abstract}

Key words: Bacillus subtilis, Colletotrichum acutatum, Trichoderma spp., biological control.

\section{INTRODUCTION}

Brazil is the world's largest producer of oranges, responsible for about $30 \%$ of fruit and $50 \%$ of juice production, with $85 \%$ of the juice marketed internationally. The crop occupies an area of approximately 839000 ha, of which $77 \%$ are located in the southeastern region of Brazil. Around $80 \%$ of the orange production in São Paulo State is destined to processing, and the juice produced is exported to countries such as Russia, Belgium, Netherlands, United States, and Japan. The remaining $22 \%$ is sent to the fresh fruit market, both for internal market and for export (Agrianual, 2011).

Though the citrus sector is of great importance, this crop faces serious phytosanitary problems. Postbloom fruit drop (PFD) caused by the fungus Colletotrichum acutatum is one of the most severe diseases of citrus. All sweet orange varieties cultivated in São Paulo State are susceptible to this disease, which is controlled with protectant and systemic fungicides sprays (Goes et al., 2008). One of the difficulties in efficiently controlling the disease by spraying chemicals is that it is more severe when long periods of rain or high humidity occur during peak flowering periods (Denham \& Waller, 1981). The occurrence of several bloom cycles also requires higher number of sprays, strongly increasing the production costs, and causing undesirable environmental consequences. Biological control is one of the alternatives to control the disease. Among the most studied antagonists are the bacterium Bacillus subtilis and the fungus Trichoderma spp. (Pusey et al., 1986; Sonoda \& Guo, 1996; Kupper \& Gimenes-Fernandes, 2002; Kupper et al., 2011, and 2012; Tronsmo \& Dennis, 1977; Gullino \& Garibaldi, 1983; Moretto et al., 2001).

According to Guetsky et al. (2001), the introduction of two or more biocontrol agents on the phylloplane may facilitate disease control, assuming that each one has different ecological needs and diverse modes of action. It may even result in an increasing control consistency. The application of antagonist mixtures has reduced the variability and enhanced the efficiency of biocontrol agents in multiple systems (Janisiewicz \& Korsten, 2002).

This work aimed to study the use of biological control agents alone, or in mixtures, for the control of postbloom fruit drop of citrus.

\section{MATERIALS AND METHODS}

\section{Microorganisms}

This study used four isolates of Bacillus subtilis (ACB-66, ACB-69, ACB-77, and ACB-83) from citrus flowers and leaves (Kupper \& Gimenes-Fernandes, 2002), four isolates of Trichoderma spp., ACB-14 and ACB-40 (Trichoderma sp.), ACB-33 (T. aureoviride), and ACB37 (T. pseudokoningii) from citrus soil (Moretto et al., 2001). All the microorganisms studied are deposited in the collection of APTA Center Citros Sylvio Moreira/ IAC, Cordeirópolis, São Paulo, Brazil. 


\section{Growth of biological control agents}

Colonies of each biological control agent (BCA) cultured on potato dextrose agar (PDA) were transferred to glass tubes containing $10 \mathrm{~mL}$ of sterile distilled water and concentrations were determined and adjusted to $1 \times 10^{4}$ cells $\mathrm{mL}^{-1}$, using a hemocytometer. An aliquot of $0.2 \mathrm{~mL}$ of each suspension of biocontrol agent was plated in Petri dishes with PDA. The cultures of bacteria and the fungi were incubated, in the dark, photoperiod of $12 / 12 \mathrm{~h}$, at $15^{\circ} \mathrm{C}$, $20^{\circ} \mathrm{C}, 27^{\circ} \mathrm{C}$, and $35^{\circ} \mathrm{C}$. Cultures from different plates were harvested at different times $(6,12,18,24,36,48,72$, and $120 \mathrm{~h}$ ) by scraping the surface of microorganism with a sterile microscope slide. The experiment was carried out in a completely randomized design with a factorial arrangement of the treatments. Cell production of the microorganisms was determined with a hemocytometer. There were three replicates (Petri dishes) for each combination of biocontrol agent $\mathrm{x}$ temperature $\mathrm{x}$ time. The data were subjected to analysis of variance (ANOVA) using the SAS statistical software (SAS Institute) and the response surface graphs were generated using the software Statistica for Windows V7.0 (Statsoft Inc.).

\section{Effect of biocontrol agents on Colletotrichum acutatum conidial germination}

The effect of BCAs alone or in mixtures on the conidial germination of the plant pathogen was assessed by the technique of water-agar placed on glass slides. Ten $\mu \mathrm{L}$ aliquots from each suspension of BCA $\left(1 \times 10^{6}\right.$ cells $\left.\mathrm{mL}^{-1}\right)$ and conidial suspension of $C$. acutatum $\left(1 \times 10^{4}\right.$ conidia $\mathrm{mL}^{-1}$ ) were placed simultaneously in demarcated areas of glass slides, previously prepared with water-agar. Controls were placed in aliquots of sterile distilled water instead of $\mathrm{BCA}$. After preparing the glass slides, they were placed in tightly sealed plastic containers containing a cotton swab soaked in sterile distilled water to maintain humidity. The cultures were incubated at $25^{\circ} \mathrm{C}$ for $14 \mathrm{~h}$, in the dark. After this period, 100 conidia selected arbitrarily were observed under an optical microscope and the percentage of germinated conidia was calculated. Conidia of $C$. acutatum were considered germinated if the length of the germ tube was equal or greater or similar to the width of the conidium. Before counting, $10 \mu \mathrm{L}$ of lactophenol cotton blue was added on the conidial suspension to prevent the development of pathogen. The experiment was arranged in a completely randomized design, with each treatment repeated eight times. The data were analyzed by ANOVA using the statistical program ASSISTAT 7.6 and the means were compared by Scott-Knot's test at 5\% probability.

\section{In vivo assay on detached flowers}

Detached Lima sweet orange (Citrus sinensis) flowers were placed in plastic boxes (Germbox), with the stems inserted in holes made into $0.5-\mathrm{cm}$ thick synthetic foam over filter paper that was soaked with sterile distilled water. The boxes were placed $70 \mathrm{~cm}$ below two germicidal lamps (Sankyo Denki G30T8, 30 watts) for 20 min before antagonist application and pathogen inoculation (Moretto et al., 2001). Biocontrol agents were grown on PDA and $10 \mu \mathrm{L}$ of suspensions containing $1 \times 10^{6}$ cells $\mathrm{mL}^{-1}$ were applied alone or in combinations on each petal. The flowers were treated with BCAs $24 \mathrm{~h}$ before inoculation with the pathogen ( $1 \times 10^{4}$ conidia $\left.\mathrm{mL}^{-1}\right)$. Flowers sprayed with C. acutatum were used as controls. Each treatment was replicated three times, and each replication consisted of one Germbox with 10 flowers. The boxes were maintained in a growth chamber at $22^{\circ} \mathrm{C}$ and a 12 -h photoperiod. The evaluation was done $72 \mathrm{~h}$ after inoculation, determining the percentage of healthy flowers. The data were analyzed by ANOVA using statistical program ASSISTAT 7.6, and the means were compared by Scott-Knott test at 5\% probability.

\section{Field experiment}

Based on the results obtained in vitro and on detached citrus flowers, the best mixtures of biocontrol agents were chosen to be tested under field conditions. The treatments were: ACB-69+ACB-37; ACB-69+ACB-77; ACB-66+ACB-37; ACB-66+ACB-77, and ACB-77+ACB37. These were compared with ACB-66, ACB-69, ACB-77, ACB-37, and with the chemical carbendazin in the growing season 2009/2010 and thiophanate-methyl in the growing season 2011/2012 following the standard strategies already used by the private property and the control without treatment. Two trials were done to test the effect of $B$. subtilis and Trichoderma alone, or in mixture, in preventing infection by $C$. acutatum.

Field Experiment 1 was conducted during the growing season 2009/2010 in 12-year-old orchards of 'Lima' sweet orange (C. sinensis) grafted on Rangpur lime (Citrus limonia) located in the municipality of Engenheiro Coelho, SP. Field experiment 2 was conducted during the growing season 2011/2012 in 20-year-old orchards of 'Lima' sweet orange (C. sinensis) grafted on Rangpur lime, located in the municipality of Estiva-Gerbi, SP. Inoculum of B. subtilis was produced on glass vessels containing 15 $\mathrm{L}$ of medium comprised of the foliar fertilizer base Ajifol at $5 \%(\mathrm{v} / \mathrm{v})$, autoclaved at $120^{\circ} \mathrm{C}$ for $60 \mathrm{~min}$, at $1 \mathrm{~atm}$. This medium contains carbon, nitrogen, and mineral sources; it is inexpensive and widely used in several citrus orchards as a foliar fertilizer. The medium was seeded with a bacterial suspension and incubated at room temperature $\left(22^{\circ} \mathrm{C} \pm\right.$ $2^{\circ} \mathrm{C}$ ), for $72 \mathrm{~h}$ under constant agitation (Kupper \& GimenesFernandes, 2002). The multiplication of Trichoderma spp. was carried out in a culture medium based on potato (200 $\mathrm{g} / \mathrm{L})$ and dextrose $(20 \mathrm{~g} / \mathrm{L})$, in a 15-L Microferm Fermentor under controlled incubation conditions $\left(22^{\circ} \mathrm{C} \pm 2^{\circ} \mathrm{C}\right)$ for 120 $\mathrm{h}$, under constant agitation. The treatments were applied using a tractor-powered sprayer, with two guns calibrated to provide an application volume of $2.000 \mathrm{~L} / \mathrm{ha}$, using $6 \mathrm{~L} /$ plant. The working pressure used was 248 kpascals, with motor rotation of $540 \mathrm{rpm}$. The treatments were applied weekly in a total of four applications during the blossom 
period according to Agustí et al. (2002): (1) closed visible flowers, or green bud, (FGB); (2) elongating flower petals; sepal covering corolla or white bud (FWB); (3) most flowers with petals forming a hollow ball (HB); and (4) open flowers (FO).

In field Experiment 2, the treatments were applied using an air-assisted sprayer calibrated to provide an application volume of $4.750 \mathrm{~L} / \mathrm{ha}$, using $10 \mathrm{~L} /$ plant. The working pressure used was 690 kpascals, with motor rotation of $540 \mathrm{rpm}$. Three applications were performed during flower growth stages (white bud, hollow ball, and open flowers). In both field experiments a final concentration of $10^{7}$ cells $/ \mathrm{mL}$ of each microorganism was used. A randomized block design was used with 11 treatments and four repetitions. Each experimental plot was composed of four plants, and the evaluations were conducted on a sample of four branches per plant from the two central plants in the plot. The evaluations were based on counting the number of diseased and healthy flowers in a sample of 12 branches per plant in Experiment 1 and three branches per plant in Experiment 2. Samples were taken from plants located at the centre of each plot. The percentage of diseased flowers followed the method adapted from Timmer \& Zitko (1996), where up to 100 flowers that had recently opened or were about to open were observed on each branch. A second evaluation was performed 90 days after the first evaluation, counting the number of fruit set and calyces retained and/ or of the yellow caused by the disease to obtain the average number of effective fruits (ANEF), using the following equation: $\mathrm{ANEF}=[\mathrm{A} /(\mathrm{A}+\mathrm{B})] \times 100$, where: $\mathrm{A}=$ number of fruit sets and $\mathrm{B}=$ number of persistent calyces and/or number of yellow fruits due to the disease, according to Goes (1995). The data were analyzed by ANOVA using statistical program ASSISTAT 7.6, and the means were compared by Tukey's test at $5 \%$ probability.

\section{RESULTS}

\section{Growth of biological control agents}

There were differences among the isolates, particularly between ACB-83 and ACB-77 that produced significantly more bacterial cells, with 2.24 and $1.91 \times 10^{9}$ cells $\mathrm{mL}^{-1}$, respectively, than isolates ACB-69 $\left(1.15 \times 10^{8}\right.$ cells $\left.\mathrm{mL}^{-1}\right)$ and ACB-66 $\left(9.43 \times 10^{7}\right.$ cells $\left.\mathrm{mL}^{-1}\right)$. The most favorable temperature for bacterial growth was $27^{\circ} \mathrm{C}$ with an average production of $2.55 \times 10^{9}$ cells mL $\mathrm{mL}^{-1}$, whereas at $15^{\circ} \mathrm{C}$ the yield was $3.69 \times 10^{7}$ cells $\mathrm{mL}^{-1}$. The yields were $9.78 \times$ $10^{8}$ cells $\mathrm{mL}^{-1}$ at $20^{\circ} \mathrm{C}$ and $8.02 \times 10^{8}$ cells $\mathrm{mL}^{-1}$ at $35^{\circ} \mathrm{C}$. There was an increase in the production of bacterial cells up to $36 \mathrm{~h}\left(5.24 \times 10^{8}\right.$ cells $\left.\mathrm{mL}^{-1}\right)$, a drop after $48 \mathrm{~h}$ of incubation $\left(2.44 \times 10^{8}\right.$ cells $\left.\mathrm{mL}^{-1}\right)$, the bacterial concentration increased again at $72 \mathrm{~h}\left(1.48 \times 10^{9}\right.$ cells $\left.\mathrm{mL}^{-1}\right)$ up to $120 \mathrm{~h}\left(9.61 \times 10^{8}\right.$ cells $\mathrm{mL}^{-1}$ ). The isolate ACB-14 (Trichoderma sp.) had the lowest number of conidia produced $\left(1.8 \times 10^{9}\right.$ conidia $\left.\mathrm{mL}^{-1}\right)$, differing significantly from the other isolates: ACB-40 (2.98 x $10^{9}$ conidia $\left.\mathrm{mL}^{1}\right), \mathrm{ACB}-37\left(2.26 \times 10^{9}\right.$ conidia $\left.\mathrm{mL}^{-1}\right)$, and
ACB-33 ( $2 \times 10^{9}$ conidia $\left.\mathrm{mL}^{-1}\right)$, which did not differ among themselves. The best temperature for fungal multiplication was $27^{\circ} \mathrm{C}\left(9.02 \times 10^{9}\right.$ conidia $\left.\mathrm{mL}^{-1}\right)$ whereas $15^{\circ} \mathrm{C}$ permitted less development of Trichoderma isolates $\left(4.2 \times 10^{6}\right.$ conidia $\left.\mathrm{mL}^{-1}\right)$. The largest number of conidia was obtained after an incubation period of $120 \mathrm{~h}\left(1.76 \times 10^{10}\right.$ conidia $\left.\mathrm{mL}^{-1}\right)$. From 6 to $18 \mathrm{~h}$ fungal sporulation almost did not occur, while at $24 \mathrm{~h}$ spore concentration was approximately $1 \times 10^{5}$ conidia $\mathrm{mL}^{-1}$. The concentration of conidia gradually increased after $36 \mathrm{~h}\left(2.70 \times 10^{6}\right.$ conidia $\left.\mathrm{mL}^{-1}\right), 48 \mathrm{~h}\left(1.84 \times 10^{7}\right.$ conidia $\left.\mathrm{mL}^{-1}\right)$, and $72 \mathrm{~h}\left(5.08 \times 10^{8}\right.$ conidia $\left.\mathrm{mL}^{-1}\right)$. Figure 1 shows some selected biocontrol agents used in this study that presented different growth and sporulation patterns.

\section{Effect of biocontrol agents on the germination of Colletotrichum acutatum}

All treatments inhibited germination of the phytopathogen, with values that ranged from $29 \%$ to $98 \%$ inhibition. Isolates of B. subtilis ACB-69, ACB-83, ACB66 , and ACB-77 inhibited $98 \%, 95 \%, 92 \%$, and $88 \%$ of $C$. acutatum germination, respectively. Isolates ACB-40, ACB14, ACB-37, and ACB-33 of Trichoderma spp. inhibited $91 \%, 86 \%, 85 \%$, and $61 \%$, respectively. The mixtures of the ACB-77 plus ACB-66, ACB-33, or ACB-37 inhibited pathogen germination from $84 \%$ to $89 \%$ (Table 1 ).

\section{In vivo assay on detached flowers}

Most isolates of B. subtilis and Trichoderma spp. (except ACB-33), when used alone, resulted in more than $86 \%$ of symptomless flowers. The bacterial isolates ACB- 66 , ACB- 83 , and ACB-69 showed 95\%, 96\%, and 99\% healthy flowers, respectively. The best treatments for controlling disease in detached flowers, using the combination of biological control agents were ACB-77 with ACB-37 or with ACB-66, with mixtures showing around $88 \%$ healthy flowers (Table 2).

\section{Control of postbloom fruit drop in the field}

In the 2009/2010 growth season (Table 3), only treatment with $T$. pseudokoningii (ACB-37) did not differ from the control (without disease control). The combined treatment ACB-37 and ACB-69 (B. subtilis) provided 73\% of healthy flowers, which did not differ from the chemical control, from ACB-66 and ACB-69; these differed from each other and had $90 \%, 86 \%$, and $81 \%$ of flowers without pathogen infection, respectively. Other treatments had intermediate results, showing percentages of healthy flowers that ranged from $33 \%$ to $65 \%$.

The average number of remaining fruits showed that although the disease had occurred with great intensity, it was possible to observe the effect of treatments on disease incidence. Plants treated with isolate ACB-69 ( $B$. subtilis) alone or combined with ACB-37 (Trichoderma pseudokoningii) did not differ significantly, either among themselves or from the standard fungicide used for the disease control, showing an average amount of healthy 
ACB-69

\section{A}

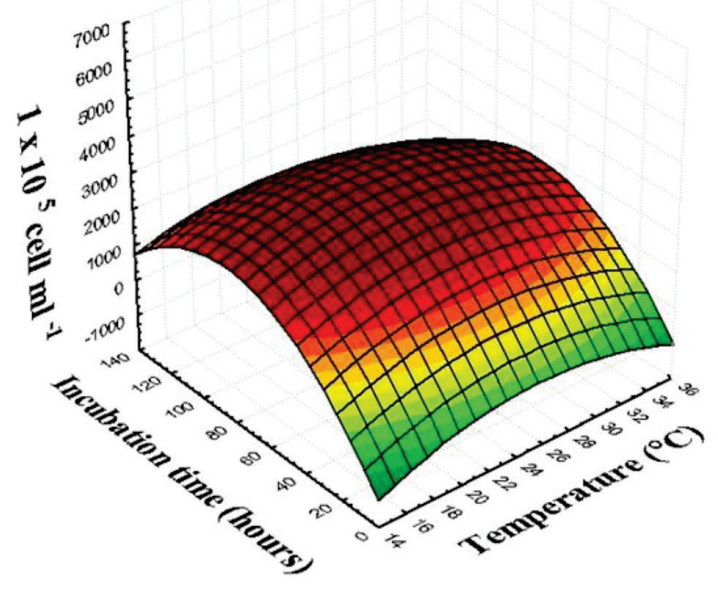

ACB-14

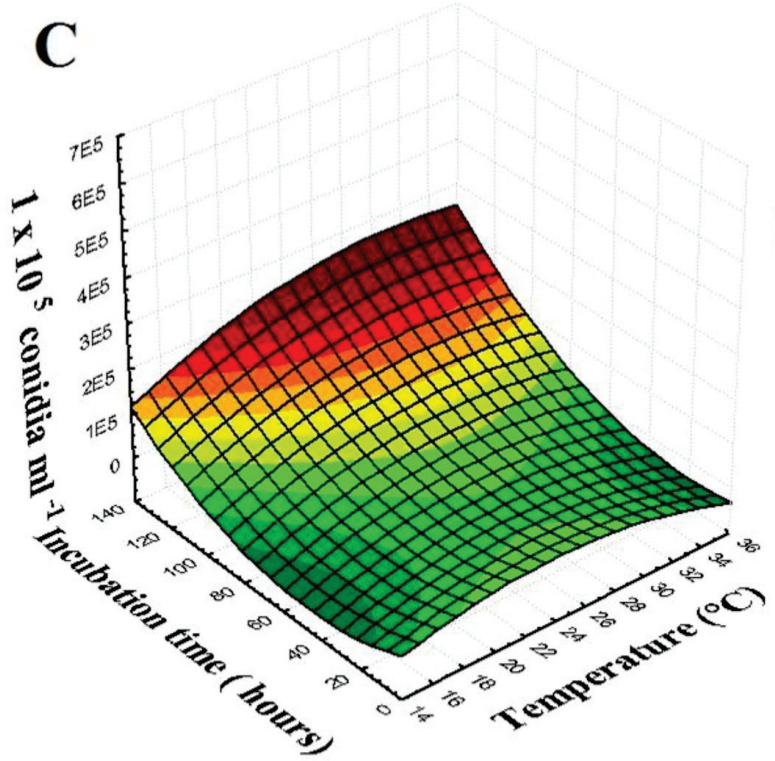

ACB-83

\section{B}

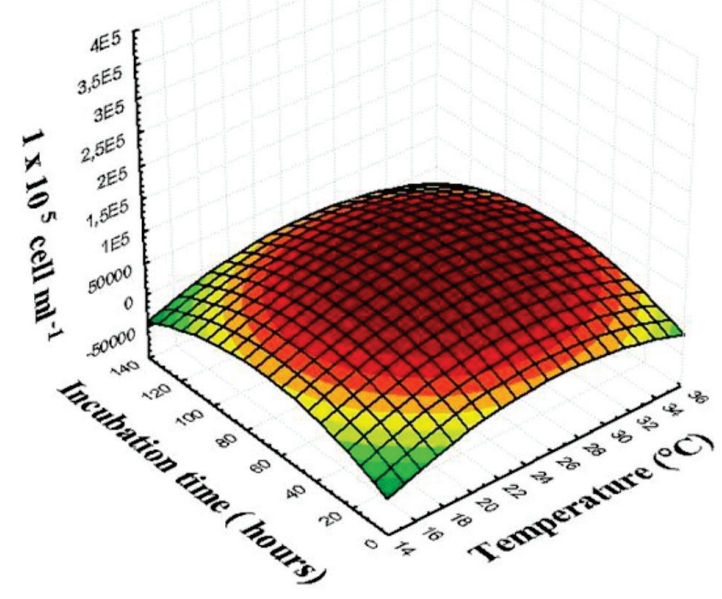

ACB-37

\section{D}

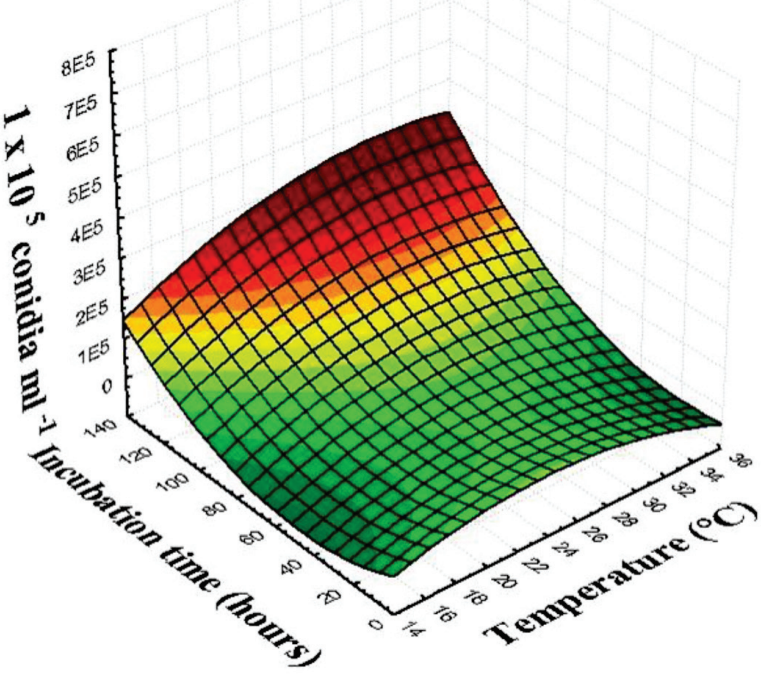

FIGURE 1 - Response surface graphs of incubation time $(6,12,18,24,36,48,72$, and $120 \mathrm{~h})$ and temperature $\left(15,20,27\right.$, and $\left.35^{\circ} \mathrm{C}\right)$ on production of cells of selected isolates of Bacillus subtilis: ACB-69 (A), ACB-83 (B), and Trichoderma sp.: ACB-14 (C) and ACB-37 (D). These isolates are shown for presenting different patterns of growth and sporulation. The experiment was done with 4 isolates of Trichoderma spp. (ACB-14, ACB-33, ACB-37 and ACB-40) and 4 isolates of Bacillus subtilis (ACB-66, ACB-69, ACB-77, and ACB-83). Isolates were incubated on different growth conditions and production of $B$. subtilis cells and Trichoderma spp. spores were determined in each period of incubation.

fruit of $41 \%, 45 \%$, and $40 \%$, respectively. Isolate ACB66 , that presented $81 \%$ of healthy flowers, showed an intermediate behavior, with $36 \%$ of an average number of effective fruits, not differing from the fungicide and the treatment with ACB-69, but differed from the mixture ACB-69+ACB-37.
The percentage of healthy flowers in the second season (Table 3) showed that, except for the treatment with ACB-37 alone, the others differed from the control. The best treatments, the chemical treatment, ACB-69 alone and the mixture of ACB-69+ACB-37 did not differ significantly from each other, with percentage of healthy flowers of 
TABLE 1 - Effect of the biological control agents, Bacillus subtilis (ACB-66, ACB-69, ACB-77 and ACB-83), and Trichoderma spp. (Trichoderma sp. - ACB-14 and ACB-40, T. aureoviride - ACB-33, and T. pseudokoningii - ACB-37), in combination or not, on the inhibition of Colletotrichum acutatum spore germination

\begin{tabular}{lccc}
\hline \hline Treatments & \% Inhibition $^{\mathrm{a}}$ & Treatments & \% Inhibition $^{\mathrm{a}}$ \\
\hline ACB-69 & $98.38 \mathrm{a}^{\mathrm{b}}$ & ACB-69+33 & $58.12 \mathrm{j}^{\mathrm{b}}$ \\
ACB-83 & $95.25 \mathrm{~b}$ & ACB-77+14 & $57.62 \mathrm{j}$ \\
ACB-66 & $92.25 \mathrm{~b}$ & ACB-37+40 & $56.00 \mathrm{j}$ \\
ACB-40 & $90.62 \mathrm{c}$ & ACB-33+37 & $55.50 \mathrm{j}$ \\
ACB-66+77 & $89.12 \mathrm{c}$ & ACB-69+66 & $55.25 \mathrm{j}$ \\
ACB-77+37 & $88.62 \mathrm{c}$ & ACB-33+40 & 51.001 \\
ACB-77 & $87.87 \mathrm{c}$ & ACB-83+40 & 50.121 \\
ACB-14 & $85.62 \mathrm{~d}$ & ACB-66+40 & $48.37 \mathrm{~m}$ \\
ACB-37 & $85.37 \mathrm{~d}$ & ACB-83+33 & $41.37 \mathrm{n}$ \\
ACB-77+33 & $84.25 \mathrm{~d}$ & ACB-69+40 & $40.37 \mathrm{n}$ \\
ACB-69+77 & $76.00 \mathrm{e}$ & ACB-83+37 & $39.50 \mathrm{n}$ \\
7ACB-66+37 & $74.25 \mathrm{f}$ & ACB-66+33 & $38.25 \mathrm{n}$ \\
ACB-69+37 & $72.00 \mathrm{~g}$ & ACB-14+37 & $34.75 \mathrm{o}$ \\
ACB-77+40 & $71.62 \mathrm{~g}$ & ACB-14+40 & $33.37 \mathrm{o}$ \\
ACB-83+77 & $69.75 \mathrm{~h}$ & ACB-14+33 & $31.87 \mathrm{o}$ \\
ACB-66+14 & $69.37 \mathrm{~h}$ & ACB-69+14 & $29.75 \mathrm{o}$ \\
ACB-66+83 & $63,00 \mathrm{i}$ & ACB-69+83 & $28.87 \mathrm{o}$ \\
ACB-33 & $60.75 \mathrm{i}$ & Control & $0.00 \mathrm{p}$ \\
ACB-83+14 & $58.62 \mathrm{j}$ & & \\
\hline
\end{tabular}

${ }^{\mathrm{a}} 100$ conidia selected arbitrarily were observed under an optical microscope and the percentage of germinated conidia was calculated. ${ }^{\mathrm{b}}$ Means followed by the same letter are not significantly different according to Scott-Knot's test $(P \leq 0.05)$.

TABLE 2 - Percentage of flowers without symptoms of Colletotrichum acutatum, in detached citrus flowers, treated with Bacillus subtilis (ACB-66, ACB-69, ACB-77 and ACB-83), and with Trichoderma spp. (Trichoderma sp. ACB-14 and ACB-40), T. aureoviride ACB-33, and T. pseudokoningii ACB-37), in mixture or not, $24 \mathrm{~h}$ before inoculation with Colletotrichum acutatum

\begin{tabular}{lccc}
\hline \hline Treatments & \% Healthy flowers ${ }^{\mathrm{a}}$ & Treatments & \% Healthy flowers $^{\mathrm{a}}$ \\
\hline ACB-69 & $98.58 \mathrm{a}^{\mathrm{b}}$ & ACB-33+37 & $58.95 \mathrm{c}^{\mathrm{b}}$ \\
Control & $96.90 \mathrm{a}$ & ACB-83+14 & $57.67 \mathrm{c}$ \\
ACB-83 & $95.67 \mathrm{a}$ & ACB-77+14 & $57.51 \mathrm{c}$ \\
ACB-40 & $94.72 \mathrm{a}$ & ACB-69+33 & $56.40 \mathrm{c}$ \\
ACB-66 & $92.05 \mathrm{a}$ & ACB-40+37 & $55.35 \mathrm{c}$ \\
ACB-77+37 & $88.58 \mathrm{a}$ & ACB-66+69 & $52.47 \mathrm{c}$ \\
ACB-77+66 & $88.01 \mathrm{a}$ & ACB-40+33 & $51.95 \mathrm{c}$ \\
ACB-37 & $87.11 \mathrm{a}$ & ACB-66+40 & $50.24 \mathrm{c}$ \\
ACB-77 & $86.95 \mathrm{a}$ & ACB-83+40 & $49.24 \mathrm{c}$ \\
ACB-14 & $85.74 \mathrm{a}$ & ACB-69+40 & $41.64 \mathrm{~d}$ \\
ACB-77+69 & $76.78 \mathrm{~b}$ & ACB-66+33 & $41.60 \mathrm{~d}$ \\
ACB-66+37 & $74.99 \mathrm{~b}$ & ACB-83+33 & $41.60 \mathrm{~d}$ \\
ACB-77+40 & $72.81 \mathrm{~b}$ & ACB-40+14 & $41.38 \mathrm{~d}$ \\
ACB-69+37 & $72.14 \mathrm{~b}$ & ACB-83+37 & $39.97 \mathrm{~d}$ \\
ACB-66+14 & $70.13 \mathrm{~b}$ & ACB-14+37 & $35.04 \mathrm{~d}$ \\
ACB-83+77 & $69.90 \mathrm{~b}$ & ACB-14+33 & $32.10 \mathrm{~d}$ \\
ACB-77+33 & $65.06 \mathrm{c}$ & ACB-69+14 & $31.57 \mathrm{~d}$ \\
ACB-83+66 & $62.61 \mathrm{c}$ & Inoc. Control & $31.07 \mathrm{~d}$ \\
ACB-33 & $60.24 \mathrm{c}$ & ACB-83+69 & $30.37 \mathrm{~d}$ \\
\hline
\end{tabular}

aDetached flowers were placed in plastic boxes (Germbox), and the biocontrol agents were inoculated, alone or in mixture, on each petal. The evaluation was done $72 \mathrm{~h}$ after inoculation with $C$. acutatum, determining the percentage of healthy flowers. ${ }^{\text {b}}$ Means followed by the same letter are not significantly different according to Scott-Knot's test $(P \leq 0.05)$. 
TABLE 3 - Effect of the mixture of biological control agents in the percentage of flowers without infections by Colletotrichum acutatum, and the average number of effective fruits (ANEF) in 'Lima 'orange plants under field conditions in Engenheiro Coelho-SP, Brazil, during the 2009/2010 season and in Estiva Gerbi-SP, Brazil, during the 2011/2012 season

\begin{tabular}{|c|c|c|c|c|}
\hline Treatments & $\begin{array}{l}\% \text { Healthy } \\
\text { flowers }^{\mathrm{a}}\end{array}$ & $\mathbf{A N E F}^{\mathrm{b}}$ & $\%$ Healthy flowers ${ }^{a}$ & ANEF $^{\mathrm{b}}$ \\
\hline & \multicolumn{2}{|c|}{$2009 / 2010$ season } & \multicolumn{2}{|c|}{ 2011/2012 season } \\
\hline Chemical control & $90.25 \mathrm{a}^{\mathrm{c}}$ & $40.20 \mathrm{ab}^{\mathrm{c}, \mathrm{d}}$ & $89.32 \mathrm{a}^{\mathrm{c}}$ & $68.85 \mathrm{a}^{\mathrm{c}, \mathrm{d}}$ \\
\hline ACB-69 & $86.12 \mathrm{a}$ & $40.55 \mathrm{ab}$ & $85.15 \mathrm{a}$ & $58.16 \mathrm{a}$ \\
\hline ACB-66 & $80.87 \mathrm{ab}$ & $35.85 \mathrm{~b}$ & $74.53 \mathrm{~b}$ & $45.10 \mathrm{~b}$ \\
\hline $\mathrm{ACB}-69+37$ & $72.50 \mathrm{abc}$ & $44.58 \mathrm{a}$ & $84.15 \mathrm{ab}$ & $64.64 \mathrm{a}$ \\
\hline ACB-69+77 & $65.00 \mathrm{bcd}$ & $9.62 \mathrm{fg}$ & $50.98 \mathrm{c}$ & $23.23 \mathrm{c}$ \\
\hline ACB-77+66 & $56.62 \mathrm{~cd}$ & $28.38 \mathrm{c}$ & $37.73 \mathrm{~d}$ & $40.78 \mathrm{~b}$ \\
\hline ACB-77 & $55.12 \mathrm{~cd}$ & $25.69 \mathrm{~cd}$ & $50.35 \mathrm{c}$ & $27.77 \mathrm{c}$ \\
\hline ACB-77+37 & $47.62 \mathrm{de}$ & $19.30 \mathrm{de}$ & $9.28 \mathrm{~d}$ & $24.22 \mathrm{c}$ \\
\hline ACB-66+37 & 32.50 ef & $26.25 \mathrm{~cd}$ & $43.15 \mathrm{~cd}$ & $29.13 \mathrm{c}$ \\
\hline ACB-37 & $17.62 \mathrm{fg}$ & $16.34 \mathrm{ef}$ & $18.53 \mathrm{e}$ & $9.40 \mathrm{~d}$ \\
\hline Control & $8.50 \mathrm{~g}$ & $8.92 \mathrm{~g}$ & $16.98 \mathrm{e}$ & $4.22 \mathrm{~d}$ \\
\hline
\end{tabular}

aThe evaluations were based on counting the number of healthy flowers in a sample of branches per plant. ${ }^{\mathrm{b}} \mathrm{ANEF}=(\mathrm{A} /(\mathrm{A}+\mathrm{B})) \times 100($ where $\mathrm{A}=$ number of fruit sets and $\mathrm{B}=$ number of persistent calyces and/or number of yellow fruits due to the disease). ${ }^{\mathrm{c}}$ Means followed by the same letter are not significantly different to according to the Tukey's test. $(P \leq 0.05)$. ${ }^{\mathrm{d}}$ Data transformed to arc sen sqrt $(\mathrm{x}+0.5)$.

$89 \%, 85 \%$, and $84 \%$, respectively. Other treatments showed intermediate control with the percentage controls ranging from $74.5 \%$ (ACB-66) and 38\% (ACB-77+ACB66). In evaluating the average number of effective fruits produced, except for treatment with the ACB-37, the other treatments differed from the control, with percentages of average number of effective fruits ranging from $69 \%$ to $23 \%$. The most effective treatments were the chemical control, the mixture (ACB-69+ACB-37) and ACB-69, with average numbers of effective fruits at $69 \%, 65 \%$, and $58 \%$, respectively.

\section{DISCUSSION}

In this study we investigated the effects of mixtures between species of Bacillus and Trichoderma to control postbloom fruit drop of citrus and observed that when these microorganisms were applied in combination disease control was reduced. The levels of control of postbloom fruit drop by isolate ACB- 69 in the experiments reported here were similar to what was obtained in other trials with the same isolate (Kupper et al., 2003, 2009, 2012). However, this was the first attempt of mixing this isolate with other biocontrol agents for control of postbloom fruit drop. We believe that isolate ACB-37 diminishes the biological control activity of ACB-69 thereby reducing the efficacy of the mixtures. This study demonstrates that certain biological control agents are incompatible. One of the isolates interferes with the mechanism by which a second isolate suppresses plant disease.

As in our study, other authors found more efficient results when the microorganisms were used individually. In studies with Trichoderma isolates for controlling root-rot of strawberry caused by Armillaria mellea, Raziq \& Fox
(2005) observed that some isolates of $T$. harzianum and $T$. hamatum were more efficient when applied individually than when mixed. Georgakopoulos et al. (2002) studied $B$. subtilis, Pseudomonas fluorescens, $P$. corrugata, $T$. viride and Gliocladium virens applied alone or in combination for controlling Pythium ultimum, and found that mixtures were less effective than individual antagonist treatments. On the other hand, Roberts et al. (2005) studied different isolates of Trichoderma and bacteria such as Serratia marcescens, Burkholderia ambifaria, and Burkholderia cepacia for biocontrol of different fungal diseases caused by Rhizoctonia solani and Pythium ultimum in cucumber and found that the combinations of biocontrol agents were more effective when compared to applications of the agents alone. The same result was found by Maketon et al. (2008), which showed that neither B. subtilis nor $T$. harzianum alone could control Ralstonia solanacearum, causal agent of bacterial wilt in tobacco, but when combined, they provided control levels similar to the chemical treatment.

Considering that microorganisms involved in mixtures may have different mechanisms of action, it is believed that the control could be optimized by reducing the variability during the suppression of diseases (Punja, 1997; Guetsky et al., 2002; Jetiyanon \& Kloepper, 2002). Biocontrol by mixing antagonists is maximized when knowledge on the biology and ecological needs of each microorganism involved is available. Compatible mixtures of biocontrol agents with different mechanisms of action may reduce the chance of resistance development by phytopathogens and may be effective over a wider range of environmental conditions. In particular, mixtures of fungi and bacteria may provide protection at different times due to their differential physiological requirements 
and mechanisms of action, which may help overcome inconsistencies in the performance of individual isolates.

According to Kupper et al. (2003) antibiosis seems to be a major mechanism involved in the interaction between B. subtilis, especially the ACB-69 isolate and C. acutatum. On the other hand, in species of Trichoderma, production of cell-wall-degrading enzymes (Kubicek et al., 2001) and mycoparasitism (Moretto et al., 2001) have been shown to be key factors in other systems. Further studies need to be performed to reveal the mechanisms used by Trichoderma to antagonize C. acutatum in citrus and improve the current understanding about its incompatibility with the Bacillus isolates used in our experiments.

The data obtained under field conditions in our study showed that when spraying biological products, the association of postbloom drop and high humidity should be considered. Prolonged periods of rain, as occurred during installation and evaluation of the experiment in August, September, and October (2009/2010 growth season) favored the development of an epidemic that diminished the effects of the biological treatments. Examples reported in the literature show that environmental conditions affect the stability, survival, and antagonistic activity of biological control agents (Elad \& Zimand, 1993; Elad et al., 1994; Dik \& Elad, 1999). This might explain why mixtures of ACB77 plus ACB-66 or ACB-37 showed efficiency only in vitro and on detached citrus flowers, where environmental conditions were controlled.

Another aspect that should be considered about mixtures of microorganisms is the formulation of the bioproduct and the concentration of every agent. In general the cost of registration of biocontrol agents is high. If a combination of biocontrol agents is attempted, each agent needs to be registered independently. This requirement will certainly increase the cost of developing a biological product as well as the cost of its use. Considering the results of our work, the application of isolate ACB-69 presents advantages to postbloom fruit drop control in terms of cost and efficacy.

\section{ACKNOWLEDGMENTS}

The financial support of Fundação de Apoio à Pesquisa do Estado de São Paulo - FAPESP is gratefully acknowledged (processes no. 2008/56390-3 to K.C. Kupper and no. 2008/09821-9 - scholarship to M.N. Klein).

\section{REFERENCES}

Agrianual (2011) Yearbook of Brazilian Agriculture. São Paulo SP, Brazil. FNP.

Agustí M, Zaragoza S, Bleiholder H, Buhr L, Hack H, Klose R, Staub R (2002) The BBCH scale for describing phenological stages in citrus development. Proceedings of the Internacional Society of Citriculture 9:445-446.

Denham TG, Waller JW (1981) Some epidemiological aspects of post-bloom fruit drop disease (Colletotrichum gloeosporioides) in citrus. Annals of Applied Biology 98:65-67.

Dik AJ, Elad Y (1999) Comparison of antagonists of Botrytis cinerea in greenhouse-grown cucumber and tomato under different climatic conditions. European Journal of Plant Pathology 105:123-137.

Elad Y, Köhl J, Fokkema NJ (1994) Control of infection and sporulation of Botrytis cinerea on bean and tomato by saprophytic bacteria and fungi. European Journal of Plant Pathology 100:315336.

Elad Y, Zimand G (1993) Use of Trichoderma harzianum in combination or alternation with fungicides to control cucumber grey mould (Botrytis cinerea) under commercial greenhouse conditions. Plant Pathology 42:324-332.

Georgakopoulos, DG, Fiddaman, P, Leifert C, Malathrakis, NE (2002) Biological control of cucumber and sugar beet damping-off caused by Pythium ultimum with bacterial and fungal antagonists. Journal of Applied Microbiology 92:1078-1086.

Goes A (2005) Podridão floral de frutos cítricos: Caracterização do agente causal, Colletotricum gloeosporioides Penz. (Sensu Arx, 1957), e controle da doença. PhD Thesis, Universidade de São Paulo. Piracicaba SP, Brazil.

Goes A, Garrido RBO, Reis RF, Baldassari RB, Soares MA (2008) Evaluation of fungicide applications to sweet orange at different flowering stages for control of postbloom fruit drop caused by Colletotrichum acutatum. Crop Protection 27:71-76.

Guetsky R, Shtienberg D, Elad Y, Dinoor A (2002) Establishment, survival and activity of biocontrol agents applied as a mixture in strawberry crops. Biocontrol Science and Technology 12:705714.

Guetsky R, Shtienberg D, Elad Y, Dinoor A (2001) Combining biocontrol agents to reduce the variability of biological control. Phytopathology 91:621-627.

Gullino ML, Garibaldi A (1983) Situation actuelle et perspectives d'avenir de la lutte biologique et integree contre la pourrite grise de la vigne en italie. Les Colloques de L'INRA Bordeaux 18:9197.

Janisiewicz WJ, Korsten L (2002) Biological control of postharvest diseases of fruits. Annual Review of Phytopathology 40:411-441.

Jetiyanona K, Kloepper JW (2002) Mixtures of plant growthpromoting rhizobacteria for induction of systemic resistance against multiple plant diseases. Biological Control 24:285-291.

Kubicek CP, Mach RL, Peterbauer CK, Lorito M (2001) Trichoderma: from genes to biocontrol. Journal of Plant Pathology 83:11-23.

Kupper KC, Bellotte JA, Goes A (2009) Controle alternativo de Colletotrichum acutatum, agente causal da queda prematura dos frutos cítricos. Revista Brasileira de Fruticultura 31:1004-1015.

Kupper KC, Corrêa EF, Azevedo FA, Silva AC (2012) Bacillus subtilis to biological control of postbloom fruit drop caused by Colletotrichum acutatum under field conditions. Scientia Horticulturae 134:139-143.

Kupper KC, Corrêa EB, Moretto C, Bettiol W, Goes A (2011) Control of Guignardia citricarpa by Bacillus subtilis and Trichoderma spp. Revista Brasileira de Fruticultura 33:11111118. 
Kupper KC, Gimenes-Fernandes N, Goes A (2003) Controle biológico de Colletotrichum acutatum, agente causal da queda prematura dos frutos cítricos. Fitopatologia Brasileira 28:251257.

Kupper KC, Gimenes-Fernandes N (2002) Isolation and selection of Bacillus spp. for biocontrol of Colletotrichum acutatum on 'Tahiti' lime detached flowers. Summa Phytopathologica 28:292295.

Maketon M, Apisitsantikul J, Siriraweekul C (2008) Greenhouse evaluation of Bacillus subtilis AP-01 and Trichoderma harzianum AP-001 in controlling tobacco diseases. Brazilian Journal of Microbiology 36:296-300.

Moretto KCK, Gimenes-Fernandes N, Santos JM (2001) Influence of Trichoderma spp. on Colletotrichum acutatum mycelial growth and morphology and on infection of 'Tahiti' lime detached flowers. Summa Phytopathologica 27:357-364.

Punja ZK (1997) Comparative efficacy of bacteria, fungi, and yeasts as biological control agents for diseases of vegetable crops. Canadian Journal of Plant Pathology 19:301-306.
Pusey PL, Wilson CL, Hotchkiss MW, Franklin JD (1986) Compatibility of Bacillus subtilis for postharvest control of peach brown rot with commercial fruit waxes, dicloran, and cold-storage conditions. Plant Disease 70:587-590.

Raziq F, Fox RTV (2005) Combinations of fungal antagonists for biological control of Armillaria root rot of strawberry plants. Biological Agriculture and Horticulture 23:45-57.

Roberts DP, Lohrke SM, Meyerb SLF, Buyer JS, Bowers JH, Bakerd CJ, Lie W, Souza JT, Lewis JA, Chung S (2005) Biocontrol agents applied individually and in combination for suppression of soilborne diseases of cucumber. Crop Protection 24:141-155.

Sonoda RM, Guo Z (1996) Effect of spray applications of Bacillus subtilis on postbloom drop of citrus. Phytopathology 86:52-60.

Timmer LW, Zitko SE (1996) Evaluation of a model for prediction of postbloom fruit drop of citrus. Plant Disease 80:380-383.

Tronsmo A, Dennis C (1977) The use of Trichoderma species to control strawberry fruit rots. Netherland Journal of Plant Pathology $83: 449-455$

TPP $\overline{\text { 2013-0017 - Received } 31 \text { January } 2013 \text { - Accepted } 23 \text { September } 2013}$ Section Editor: Jorge Teodoro de Souza 